\section{Dehumanized and Demonized Refugees, Zombies and World War Z}

\begin{abstract}
This paper explores inhuman/human constructions that feature in state responses to refugees. We move beyond straightforward normative claims that dehumanizing or demonizing refugees is unfair, unjust or bad to ask: what kind of inhuman monsters are refugees characterized as when they are 'demonised'; and, what are the consequences of such a characterization? Our argument is that reading the demonised refugee as the contemporary zombie monster and inversely, reading the resurgence of the zombie monster through the prism of the so-called refugee and migrant crisis, reveals the precise anxieties brought about by refugees and asylum seekers. In particular, we claim that both figures represent the transgression of borders, as well as the failure of containment, borders and border walls as a response to crisis. We also argue that the contemporary zombie, as a race-less catchall- monster figurebogeyman, mirrors the erasure of colonial histories, race and race relations in the casting of refugees as dehistoricized, invading and disorderly bodies. We analyse these themes through the 2013 blockbuster film World War $Z$ (dir. Marc Foster). In the film, the United Nations, US Navy, World Health Organisation, and Gerry Lane (a former UN employee) combine to fight a global zombie war.
\end{abstract}

Key words: refugees; zombies; migrant crisis; border control; bare life; monsters

\section{Introduction}

In the Australian context, and internationally, it is almost passé to observe that refugees are dehumanized and demonized. In 2011, for example, the UN High Commissioner for Human Rights in the Pacific called on Australian political leaders to break their 'ingrained political habit' of 'demonising refugees;' and in 2017, Amnesty International's annual Global Report found that the 'politics of demonisation' surrounding refugee and migrants was creating a 'divided and dangerous world' and breeding division and fear. ${ }^{2}$ We begin with these observations not so much to critique the exclusion of refugees and asylum seekers from the category of human, but to ask: what kind of inhuman monsters are refugees characterized as when they are 'demonised'; and, what are the possibilities and consequences of such a characterization?

\footnotetext{
${ }^{1}$ K Needham, 'Stop demonising refugees, says UN', Sydney Morning Herald, 28 September 2011, https://www.smh.com.au/national/stop-demonising-refugees-says-un-20110927-1 kvh4.html (accessed 22 May 2018).

2 'Politics of demonization' breeding division and fear', Amnesty International, 27 February 2017 , https://www.amnesty.org/en/latest/news/2017/02/amnesty-international-annual-report-201617/ (accessed 22 May 2018); see also Amnesty International, The State of the World's Human Rights (2017).
}

Commented [A1]: Adding this to help with search term optmisation as people need a cite for this always. What say you??

Commented [A2]: Changed this to eliminate similarity with phrasing in one of the zombie history pieces I read as we don't cite it in the intro.

Commented [A3]: C

Commented [A4R3]: 
Bringing our focus to the precise kind of demon or non-human figure that is ascribed to the refugee allows us to identify the precise threats believed to be posed by the mobile asylumseeking subject. Our argument is that reading the demon(ised), monstrous refugee as the contemporary zombie monster and inversely, reading the resurgence of the zombie monster through the prism of the so-called refugee and migrant crises, reveals the precise anxieties brought about by refugees and asylum seekers. We show that the anxieties connected to and generated by refugee movement reflect the monstrous qualities of the zombie. In particular, we claim that both figures represent the transgression of borders, including borders between the human and inhuman and the dead and undead, as well as the failure of containment, borders and border walls as a response to crisis. We also argue that the contemporary zombie, as a race-less catchall bogeymanmonster figure, mirrors the erasure of race and race relations in the casting of refugees as dehistoricized, invading and disorderly bodies.

Tracing the refugee-as-zombie trope is productive as it moves us beyond straightforward normative claims that dehumanizing or demonizing refugees is unfair, unjust or bad. It allows us to ask what the implication of such processes are and indeed, what can then be done to the dehumanised subject, to the refugee or zombie-as-contaminant or threat. This reflects Cole's insight that the label of monstrous wickedness is instrumental and serves a narrative purpose of justifying and requiring extreme responses. ${ }^{3}$ In each section we analyze state responses to refugee populations seeking protection through the depiction of the undead in the 2013 film World War Z. ${ }^{4}$ We argue that even though the film itself may primarily be, as MacNeil has argued, an empty vehicle for 'Hollywood himbo' Brad Pitt to once again save the world, ${ }^{5}$ in its depiction of the zombie war it cannot help but both represent and critique fears that refugee populations will contaminate systems of national order, as well as unsettling present day responses - of containment and securitization - to the so-called refugee crisis.

After introducing the film, we analyze three intersections of monster and zombie theory with representations and responses to refugee movement. They are the transgression of borders between the human/inhuman and the dead/undead; the irrelevance and breakdown of the geopolitical, territorial state; and the erasure of colonial histories, global inequality and race in narrating the 'origin' of the refugee crisis and of the zombie war/virus. Finally, we examine the 'other' refugee story presented in World War Z and zombie texts more generally - that of the uninfected - which is represented in the film by the story of Gerry Lane and his white, American family.

\footnotetext{
${ }^{3}$ P Cole, The Myth of Evil (Edinburgh University Press Ltd, Edinburgh 2006) 256.

${ }^{4}$ World War Z (2013).

${ }^{5}$ W Macneil, 'The Litigating Dead: Zombie Jurisprudence in Contemporary Popular Culture' (2017) 14 NoFo: An interdisciplinary journal of law and justice 108.
} 


\section{World War Z's Zombies and Border-Crossing Refugees}

The novel World War $\mathrm{Z}$ and resulting film, and their commercial successes, are part of the zombie zeitgeist. World War Z: An Oral History of the Zombie War is an apocalyptic horror novel written by Max Brooks. ${ }^{6}$ The book provides a series of personal accounts of the impacts of the devastating global conflict against a zombie plague. Brooks used the novel to critique US isolationism and government ineptitude. ${ }^{7}$ The novel was a commercial hit and was praised by most critics. ${ }^{8}$ A film, with the same name as the novel, was released in 2013, directed by Marc Forster and starring Brad Pitt as the main character, Gerry Lane, a former UN investigator who must travel the world to find a way to stop the zombie pandemic. The film departed greatly from the book's premise, to the extent that a critic asserted it had 'cannibalised' the novel, ${ }^{9}$ focusing on the present and making it more of an action film. ${ }^{10}$ The film watered down some of the book's explicitly political undertones to produce a commercially successful summer blockbuster. ${ }^{11}$

The film was a commercial success, grossing over USD540 million, becoming the highest grossing zombie film of all time. Critical responses to the film were mixed. On the one hand critics labelled it as a 'punchy, if conventional action thriller', ${ }^{12}$ and on the other as 'an anemic actioner that fosters excitement like dead limbs as it lumbers towards a conclusion'13 and with 'no heart to be found among the guts' ${ }^{14}$ Even though this was an intentionally depoliticized film, ${ }^{15}$ we argue that its outwardly sanitized storyline and imagery still (cannot help but) provide insight into state-driven anxieties about migrants along the border and the failure of securitized responses to refugees. The politics of the apparently less controversial adaptation of the book

\footnotetext{
${ }^{6}$ M Brooks, World War Z: An Oral History of the Zombie War (Crown, USA 2006).

7 'Exclusive Interview: Max Brooks on World War Z', eatmybrains, 20 October 2006, http://www.eatmybrains.com/showfeature.php?id=55 (accessed 14 May 2018).

${ }^{8}$ The novel spent four weeks on the New York Times Best Seller List: 'BEST SELLERS: October 15, 2006', New York Times, 15 October 2006,

https:/query.nytimes.com/gst/fullpage.html?res=9C0DEEDA1530F936A25753C1A9609C8B63 (accessed 28 November 2017).

9 J Neumaier, 'World War Z' review: Brad Pitt's pit against zombies, but star can't breathe life into predictable flick', NY Daily News, 18 June 2013, http://www.nydailynews.com/entertainment/tv-movies/one-star-review-world war-zzzzzz-article-1.1375665 (accessed 28 November 2017).

${ }^{10}$ In 2012, Brooks stated that the film now had nothing in common with the novel other than the title.

11 'Brad Pitt: 'World War Z bogged down in politics", The Press, 29 March 2013,

http://www.yorkpress.co.uk/leisure/showbiz/10323267.Brad Pitt World War Z bogged down in politics (accessed 28 November 2017).

${ }^{12}$ H Barnes, 'World War Z - first look review', The Guardian, 8 June 2013,

https:/www.theguardian.com/film/2013/jun/07/world-war-Z-review?INTCMP=SRCH (accessed 28 November 2017).

${ }^{13}$ Neumaier (n 9).

${ }^{14}$ R Collin, 'World War Z, review', The Telegraph, 19 June 2013, http://www.telegraph.co.uk/culture/10095159/World-War-Z-review.html (accessed 28 November 2017).

${ }^{15}$ Although see the critique by Hertzberg who criticizes the politics of the film as 'threatening to eat our brains': H Hertzberg, 'World War Z-Z-Z-Zion?', The New Yorker, 23 June 2013, https://www.newyorker.com/news/hendrikhertzberg/world-war-z-Z-Z-zion (accessed 22 May 2018).
} 
reveal how the erasure of colonial histories, of responsibility, and of race relations frame the socalled migrant crisis in the same way they frame the fictional zombie war.

\section{i. The Border between the Human/Non-Human and the Breach of State Borders}

According to Foucault, each age has its 'privileged monster' - the bestial human in the Middle Ages, Siamese or conjoined twins in the Renaissance and the hermaphrodite in the Classical Age. ${ }^{16}$ Based on the sheer number of popular television series, films, video games, graphic novels and literature, it is arguable that zombies are a privileged monster in contemporary society. ${ }^{17}$ As one film critic put it after World War Z's release, '[t]his has already been a heady century for cinema's undead'. ${ }^{18}$ This resurgence in zombies has likewise been reflected in academic literature, analyzing the various cultural anxieties and challenges that the zombie represents, ${ }^{19}$ such as invasion, contagion, terror and/or the consequences of consumption and consumerism. $^{20}$

${ }^{16}$ M Foucault, Abnormal: Lectures at the College De France 1974-1975 (Picador, New York 2003) 64-65. Sharpe disputes Foucault's assertion of a linear development in monsters and notes that hermaphrodites were not part of the monster category in English common law: A Sharpe, Foucault's Monsters and the Challenge of Law (Routledge, London and New York 2010).

${ }^{17}$ Literature includes M Brooks, The Zombie Survival Guide: Complete Protection from the Living Dead (Penguin, London 2003); M Brooks, World War Z: An Oral History of the Zombie War (Random House, New York 2006); S Jones, Zombie Apocalypse! Fightback (Little Brown Book Group, London 2012); S Grahame-Smith, Pride and Prejudice and Zombies (Quirk Books, United States2009). Films include 28 Days Later (2002), Resident Evil (2002), Dawn of the Dead (2004), Shaun of the Dead (2004), Day of the Dead (2008), Diary of the Dead (2008), Zombie Strippers (2008), Fido (2006). The film Rezort (2016) involves rich tourists shooting zombies at a resort, which renews its stock by turning refugees into zombies. Series include The Walking Dead (2004) (now in season 8), Fear the Walking Dead (2015) (now in season 4), Ash vs Evil Dead (2015) (now in season 3), From Dusk Till Dawn (2014), and Dead Set (2008). For further information see the zombie movie database http://www.zmdb.org (accessed 8 March 2018). Zombies have also infiltrated video games. Resident Evil was released originally for Sony Playstation in 1996 and by 2004 had sold more than 25 million units and then led to the film series Resident Evil. ${ }^{18}$ D Cox, 'World War Z unleashes an unedifying breed of zombie', The Guardian, 17 June 2013,

https://www.theguardian.com/film/filmblog/2013/jun/17/world-war-z-zombies-brad-pitt (accessed 22 May 2018).

${ }^{19}$ Tudor notes that some theorists provide an ideographic justification for the appeal of horror movies. For example, Jancovich asserts that alien horror movies of the 1950s reflect implementation of corporate or Fordist modes of organisation in post-war era and are thus responses to a growing anxiety about the technocratic regulation of American society: M Jancovich, Horror (Batsford, London 1992) 62. Many films and series focus on what survives in the event of a zombie apocalypse: K Bishop, 'Dead Man Still Walking: Explaining the Zombie Renaissance' (2009) 37(1) Journal of Popular Film and Television 16-25; P Crofts, 'Killing to Survive: The Walking Dead, Police Slayings and Medieval Malice' (forthcoming) Law Culture Humanities

${ }^{20}$ A Thompson and A Thompson (eds.), But If a Zombie Apocalypse Did Occur (Contributions to Zombie Studies) (McFarland, Jefferson 2015); R Greene and S Mohammed (eds.), Zombies, Vampires, and Philosophy: New Life for the Undead (Open Court, Chicago 2010); S McGlotten and S Jones (eds.), Zombies and Sexuality: Essays on Desire and the Living Dead (McFarland, Jefferson 2014); T Platts, 'Locating Zombies in the Sociology of Popular Culture' (2013) 7 Sociology Compass 547; in the Australian context see also S. Ahmed, Islamophobia: Night of the Muslim Zombie An Art Series and Essay (2015). 
Central to the construction of the monstrous in the horror genre is the transgression of the borders of humanity - a disturbance of the 'natural order'. ${ }^{21}$ The specific border changes from story to story, but the function of the monster remains the same - 'to bring about an encounter between the symbolic order and that which threatens its stability'.22 Monsters are 'categorically contradictory, incomplete, or formless' ${ }^{23}$ They break apart the 'either/or' syllogistic logic with a kind of reasoning closer to 'and/neither'. The zombies, depicted in World War Z, are monsters that transgress the border of the living and the dead - they are neither/both dead nor/and alive. Zombies generate fear and fascination because they not only break rules and cross borders, but because they also challenge the border itself, by being both and neither one thing and another. They embody and unleash the chaos that exists on the other side of cultural and categorical boundaries.

Zombies as the living/dead has resonated in academic literature analyzing undocumented migrants. ${ }^{24}$ Where academics have engaged with zombie fiction it has predominantly been to gain insight into the characterization of refugees through the prism of the living-dead, connecting the zombie figure to Agamben's conception of homo sacer or bare life. ${ }^{25}$ Like the encamped political refugee, zombies have been theorized as embodiments of bare life since zombies are neither human or inhuman but necessarily 'stripped of political status ... wholly reduced to bare life' ${ }^{26}$ They can be killed but not sacrificed, since they are outside the normal legal order, but their exclusion or 'inclusive exclusion' constitutes a state or space of exception that structures the very relation of all life to bios (political life). Theorists have pointed to the ways in which:

[1]ives lived on the margins of social, political, cultural, economic and geographical borders are lives half lived. Denied access to legal, economic and political redress, these

${ }^{21}$ N Carroll, The Philosophy of Horror or Paradoxes of the Heart (Routledge, New York 1990) 52.

22 B Creed, 'Horror and the Monstrous Feminine: An Imaginary Abjection' in B Keith (ed.), The Dread of Difference: Gender and the Horror Film (University of Texas Press, Austin 1996) 35-63. In some stories, the monstrous is produced at the border between life and death (vampire and zombie stories), the normal and the supernatural (The Exorcist (1973), The Omen (1976), The Nightmare on Elm Street series, Stranger Things (2016)), between human and beast (Dr Jekyll and Mr Hyde (1941)).

${ }^{23} \mathrm{~N}$ Carroll, 'The Nature of Horror' (1987) 46(1) The journal of aesthetics and art criticism 51, 55.

${ }^{24}$ W Schinkel, “'Illegal Aliens” and the State, or: Bare Bodies v the Zombie' (2009) 24 International Sociology 779; K Slotwinska, 'The Rising Multitudes: Zombie Invasion and the Problem of Biopolitics in Max Brooks World War Z' (2015) 9 Polish Journal for American Studies 151; S Pokornowski, 'Vulnerable Life: Zombies, Global Biopolitics, and the Reproduction of Structural Violence' (2016) 5(71) Humanities 12; J Stratton, 'Zombie trouble: Zombie texts, bare life and displaced people' (2011) 14(3) European Journal of Cultural Studies 26; J Comaroff and J Comaroff, 'Alien Nations: Zombies, Immigrants and Millennial Capitalism' (2002) 101(4) The South Atlantic Quarterly 779; L Fiske, 'Human Rights and Refugee Protest against Immigration Detention: Refugees' Struggles for Recognition as Human' (2016) 32(1) Refuge 18.

${ }^{25}$ See especially J Stratton, 'Zombie Trouble: Zombie Texts, Bare Life and Displaced People' (2011a) 14(3) European Journal of Cultural Studies 265.

${ }^{26}$ G Agamben, The State of Exception, (University of Chicago, Chicago 2005) 4, trans K Attell; G Agamben, Homo Sacer: Sovereign Power and Bare Life (Stanford University Press, Palo Alto 1998) trans D Heller-Roazen. 
lives exist in a limbo-like state that is largely preoccupied with acquiring and sustaining the essentials of life. ${ }^{27}$

Humans who are precariously positioned legally as bare life, can then be characterized and treated in ways that are similar to those of zombies - as fundamentally threatening to the living, or political life, in their quest for survival. ${ }^{28}$ Stratton has argued that the same rhetoric is used for displaced people and zombies as a means of articulating and exploring the relationship between bare life and the modern state. ${ }^{29}$

Rather than focus on the zombie as bare life or as in limbo between death and (political) life, in this section we draw attention to how the key visual cues and narrative functions of zombies that they travel in unbounded and undifferentiated groups, are constantly on the move, and are always seeking new life/brains to sustain life - mirror the ways in which certain groups and images are encoded as refugees, and in turn how those groups are characterized as dangerous and unwelcome. The border crossing, hungry zombie is the unlawful, job-seeking economic refugee and vice versa.

World War $Z$ depicts the ways in which zombie monsters transgress not only symbolic or natural borders but also state borders. We were originally inspired to consider the portrayal of refugees through the prism of World War $Z$ because of the awesome spectacle in the novel and film of the Israeli cordon sanitaire around Jerusalem, and the breaching of this wall by a seething mass of zombies. ${ }^{30}$ Israel/Palestine (called the New Palestine in the novel) is one of the only countries to have successfully kept the zombies out and protected its territory, via the Israel/Palestine wall. ${ }^{31}$ In the novel, Israel only admits uninfected Jews and Palestinians within its borders. ${ }^{32}$ In the film, the New Palestine is more international - with Mossad chief Warmbrunn stating 'Every human being we save is one less zombie to fight'. This reflects the division of the world into us and

${ }^{27}$ A Downey, 'Zones of Indistinction: Giorgio Agamben's Bare Life and the Politics of Aesthetics' (2009) 223(2) Third Text 109, 109.

${ }^{28}$ J Stratton, 'Zombie Trouble: Zombie Texts, Bare Life and Displaced People' (2011b) 14(3) European Journal of Cultural Studies 265, 267; J Stratton, 'The Trouble with Zombies: Bare Life, Muselmanner and Displaced People' (2011a) 1(1) Somatechnics 188

${ }^{29}$ J Stratton, 'Zombie Trouble: Zombie Texts, Bare Life and Displaced People' (2011b) 14(3) European Journal of Cultural Studies 265, 267.

${ }^{30}$ This scene is a set piece in the film and featured in advertising for the film. When we presented this paper at the Australasian Society of Law, Literature and Humanities (Melbourne, December 2017) we were asked if the film presented Israel as the hero state. The question of whether the film was pro-Israel was also raised in the media as a consequence of the featuring of the Jerusalem wall in all advertisements for the film. See also R Israeli, Israel's Nightmares: Palestinian and Muslim Zombies Haunting Israel (Strategic Book Publishing and Rights Co, USA 2015).

31 The other country to have successfully survived the zombie onslaught is North Korea - by removing the teeth of the all its citizens. Hertzberg commented that this results in a curious political pairing of North Korea surviving due to its dictatorship and Israel by building a wall: Hertzberg (n 15).

${ }^{32}$ In the novel, after an initial civil war started by Israel's ultra-orthodox zealots who rise in rebellion, Israel and Palestine join forces to contain the outbreak. 
them - and they are trying to eat 'us' - the living. When Gerry arrives in Israel he is impressed by the international flavor of the New Palestine, humans united against the threat of zombies. People who have taken refuge in the walled city start loudly singing, literally living in harmony. The zombies are attracted to noise and start climbing over each other to breach the walls. Within minutes, the city is overrun by zombies.

The portrayal of the zombies - as a heaving undifferentiated mass of dangerous border-crossers with potential to take over a city if they gain access - mirrors and directly calls up metaphors and images used to describe and depict refugee arrivals. ${ }^{33}$ The scenes of an infected mass breaching the new border wall directly references (and willfully exaggerates) the usually placeless images of masses of refugees and migrants in transit, at sea or climbing over the top of border fences. Most recently, images during the 2015/6 'refugee crisis' consistently showed masses of people, mainly Syrians, breaching border fortifications from Syria into Turkey, from Serbia and Croatia into Hungary, and from Hungary into Austria. ${ }^{34}$ In her analysis of how Austrian newspapers write about asylum seekers, Elizabeth El Refaie quotes an article that writes of 'new hordes of applicants for asylum'. Whilst 'horde' suggests an irrational mass, El Refaie states:

In other articles, the 'war' metaphor is also evoked by verbs, which describe the refugees as 'forcing their way' (drängen) over the border into Europe, of 'invading' (eindringen) Germany and of 'storming' (stürmen) Fortress Europe. ${ }^{35}$

These metaphors of 'war' have similarly been invoked in Australia's response to refugee arrivals. For example, Australia's Department of Home Affairs oversees Operation Sovereign Borders (OSB), which the Department describes as 'a military-led border security operation aimed at combating maritime people smuggling and protecting Australia's borders' ${ }^{36}$ Since 2013 the primary focus of this 'militaristic joint agency task force' has been the interception and turning back of asylum-seeker boats. Most of its work is kept secret on the grounds of national security, though monthly 'operational updates' provide cursory, warlike summaries of activity for the relevant 'reporting period'. ${ }^{37}$ In World War Z, the very title of the novel and film makes it

33 '[Z]ombies have become phantasmal stand-ins for Islamic terrorists, illegal immigrants, carriers of foreign contagions and other dangerous border crossers': R Saunders, 'Undead Spaces: Fear, Globalization, and the Popular Geo-Politics of Zombiism' (2012) 17 Geopolitics 80.

${ }^{34}$ A Hartocollis, 'Traveling in Europe's River of Migrants', The New York Times, 5 September 2015,

https://www.nytimes.com/interactive/projects/cp/reporters-notebook/migrants/hungary-treatment-refugees (accessed 22 May 2018).

${ }^{35}$ E El Refaie, 'Metaphors We Discriminate By: Naturalised Themes in Austrian Newspaper Articles About Asylum Seekers' (2001) 5(3) Journal of Sociolinguistics 352, 364-65, cited in J Stratton, 'Zombie Trouble: Zombie Texts, Bare Life and Displaced People' (2011b) 14(3) European Journal of Cultural Studies 265 and S Pickering,

'Common Sense and Original Deviancy: News Discourses and Asylum Seekers in Australia' (2001) 14(2) Journal of Refugee Studies 169.

36 'Operation Sovereign Borders', Department of Home Affairs, 18 September 2013, http://osb.homeaffairs.gov.au/ (accessed 22 May 2018)

37 'Newsroom: Operation Sovereign Borders', Australian Border Force, 
clear that the zombie pandemic is regarded as a war between the living and the living-dead. The zombies are portrayed as a mindless throng threatening the destruction of order, prosperity, security, and the very existence of the state. ${ }^{38}$

In World War Z, the zombies almost always travel in mobs (leaving aside the zombie doctors in the laboratory at the end who are isolated from each other by security doors) ${ }^{39}$ It is very rare for the film to portray a zombie as an individual - and when this does occur, it is usually a close up to show infection and then the film moves on without any follow up of what happened to that particular zombie. ${ }^{40}$ Likewise, refugees, except in certain circumstances or in death, are presented or discussed as a collective and, for the most part, not even as a specific national or ethnic group. Usually, like the zombies in World War Z, refugees and 'illegal' migrants are represented as a group crossing or attempting to cross borders. As Mountz and Hyndman note, in the process of conflating public discourse 'about terrorists, refugees, economic migrants, human smuggling and others on the move', individual people are stripped of their identities and resubjectified as groups - and as threatening groups at that. ${ }^{41}$

Arguably, the most well-known 'fact' about the migrants and refugees arriving in Europe in the last few years, and especially in 2015, is the scale of their arrival - namely that over 1 million migrants reached Europe that year, and that over 800,000 reached Greek territory by sea. ${ }^{42}$ In the context of the so-called 'refugee crisis', descriptions are prefaced with a vague numerical reference: $100 \mathrm{~s}$ or $1000 \mathrm{~s}$ or millions. As Manderson explains in regard to refugees travelling by boat, we are presented with 'abject bodies of mainly unidentifiable refugees' who are positioned ad nauseum (quoting Ruskin) on 'the deathfulness of the open, deep, illimitable sea' ${ }^{43}$ For asylum seekers who are depicted as 'anonymous, impotent, barely human', there is not a demand for justice as might belong to the human-citizen - but at best and following Arendt, a 'plea for mercy'. ${ }^{44}$ Further, as Justine Poon has argued in relation to so-called 'boat arrivals' in Australia,

http://newsroom.border.gov.au/channels/Operation-Sovereign-Borders (accessed 22 May 2018).

${ }^{38}$ R Saunders, 'Undead Spaces: Fear, Globalization, and the Popular Geo-Politics of Zombiism' (2012) 17(1) Geopolitics 80

${ }^{39}$ The genre usually includes 'dead kindred' i.e. the known dead to increase the emotional resonance through recognition of the zombie and the requirement of resolution, that is, the killing of a zombie who is still recognizable as a former loved one. R. H. W. Dillard, 'Night of the Living Dead: It's Not Just Like a Wind That's Passing Through', in G Waller (ed.), American Horrors (University of Illinois Press, Illinois 1987) 15. In World War Z, Gerry only needs to circumnavigate the zombie doctors. There is no requirement of painful resolution.

40 The majority of the genre (leaving aside zombie rom-coms) presents zombies as an undifferentiated mass. Notable exceptions include S.G. Browne, Breathers: A Zombie's Lament (Three Rivers Press, USA 2009), M.R Carey The Girl with all the Gifts (Little, Brown \& Company, New York 2015) and Shaun of the Dead (2004). ${ }^{41} \mathrm{~J}$ Hyndman and A Mountz, "Another Brick in the Wall? Neo-Refoulement and the Externalization of Asylum by Australia and Europe" (2008) 43 Government and opposition 249, 258.

42 'Irregular Migrant, Refugee Arrivals in Europe Top One Million in 2015: IOM', IOM, 22 December 2015, https://www.iom.int/news/irregular-migrant-refugee-arrivals-europe-top-one-million-2015-iom (accessed 22 May 2018).

${ }^{43}$ D Manderson, 'Bodies in the Water: On Reading Images More Sensibly' (2015) 27(2) Law and Literature 279 , 286

${ }^{44}$ Ibid, 285. 
asylum seekers become disembodied and unwelcome 'boats' in Australian political discourse. ${ }^{45}$ She writes that these metaphors have played a central role, in complicity with law, in enacting the disappearing of the actual asylum seekers and constructing an emptied legal subject whose presence is registered just enough by the law in order to capture it within a system of state coercion, movement, and detention.

There have been repeated and careful critiques of the usually water-based metaphors use to describe refugees, such as floods, swamps, deluges, waves, tsunamis, pipelines, flows and streams. What connects these metaphors, alongside the recurring theme of refugee arrival as natural disasters, is that these disaster or weather events are generally limitless and uncontainable. Walls or geographic borders are either vulnerable or entirely redundant in the face of natural disasters. Critiquing these metaphors and coded language, Lani Kainz argues that human beings cannot flood, flow or stream. ${ }^{46}$ By contrast, in the World War Z cordon sanitaire breach scene, the zombies do flow and flood. In their many thousands, they quite literally spill over the wall and flood the city, exemplifying and parodying anti-immigrant fears. ${ }^{47}$

In reading the refugee mass as a zombie mass, though, there is no plea for justice or mercy for the zombies - only the danger and threat posed to the no-longer-secure nation state. Calls for empathy or sympathy towards the zombies in World War $Z$ are absent. However, as the zombies breach the wall and infect the humans, there is estensiblyno longer a clear boundary between 'us' and 'them' (though we return to and critique this claim below). There is no capacity to contain the monstrous hordes, which leaves a distinct sense of unease at the extrajudicial murder of the human-inhuman zombies who are entirely disposable and yet not entirely separate from the citizen-human within.

\section{ii. Border Failure, the Territorial Nation State and Immigration Control}

In the securitized state, borders do not just denote the boundaries of the territorial state but are cast as key sites from which the safety and security of the nation can and should be guaranteed and protected. A conception of the nation-state as a container, which serves to clearly differentiate one polity from another, still orders national identity and security around concepts such as territoriality, geographical limits, entries, and exits. ${ }^{48}$ Governments present territorial

45 J Poon, 'How a body becomes a Boat: The Asylum Seeker in Law and Images' (2018) 30(1) Law and Literature 105.

${ }^{46}$ L Kainz, 'People Can’t Flood, Flow or Stream: Diverting Dominant Media Discourses on Migration', 8 February 2016, https://www.law.ox.ac.uk/research-subject-groups/centre-criminology/centrebordercriminologies/blog/2016/02/people-can\%E2\%80\%99t (accessed 22 May 2018).

${ }^{47}$ I Heilikmann, 'Escaping the Sea of Zombies: Lessons Learned from Climate Change Refugees' (2016) 14(1) Canberra Law Review 63. See also Human Flow, 2017 (dir. Ai Weiwei).

${ }^{48}$ D Bigo, 'Security and Immigration: Toward a Critique of the Governmentality of Unease' (2002) 27 (Issue 1 Supplement) Alternatives 63, 65; see also A Vogl, 'Over the Borderline: A Critical Inquiry into the Geography of Territorial Excision and the Securitisation of the Australian Border' (2014)38(1) University of New South Wales Law Journal 114. 
borders and their regulation as central to national security, and preventing the arrival and potential arrival of undocumented migrants is one of the key objectives of border control and protection..$^{49}$ As a result, national security has come to mean controlling who enters the State and on what terms, as well as affording the State summary powers to expel migrants. ${ }^{50}$

In World War Z, the hero, Gerry, originally visits Israel/Palestine as it is considered to be the only state to be 'winning' the zombie war via its (to parody Trump) 'beautiful wall' and perfection of containment and protection of its citizens. Gerry is still on a quest to head to India to find the original virus. The Chief of Mossad points out that finding the origin of the virus is pointless, telling him, 'India is a black hole, forget about Patient zero', but Gerry retorts, 'I can't do that, it's too late for me to build a wall'.

In the same scene we described above of the breach of New Palestine's cordon sanitaire, and in the images of boundaries throughout the film, the wall is at first presented as an ingenious and foresighted 'solution' to the crisis for the citizens of New Palestine, and as a safe barrier between citizen/non-citizen or zombie/human. It is a jarringly familiar form of immigration control..$^{51}$ Initially, Gerry's visit to the New Palestine and sanctuary behind the wall provides a reprieve for him and for viewers: at last, some humans are safe. However, the profound breach of the wall and impressive scenes of zombies hurtling themselves headlong over the top of the wall - is a visual representation of the critiques of the global securitization of migration, of border walls, and of the inside/outside dyad as a means of 'securing' the nation..$^{52}$ Following Gerry's lament that it is too late for him to build a wall, we watch the irreversible failure of the wall to protect or seal off those taking shelter within. Once the zombies arrive, no one is protected from infection. The wall that was protecting the living now entraps them. The film zooms in on member after member of the Israeli Defence Force (and former border guards) getting bitten and becoming the enemy.

Monsters stalk, threaten and wreak havoc until the bitter end of horror stories and often beyond, allowing for sequels. ${ }^{53}$ World War $\mathrm{Z}$ shows that deploying ordinary measures or tactics against

${ }^{49}$ C Dauvergne, 'Security and Migration Law in a Less Brave New World' (2007) 16 Social and Legal Studies 533 ${ }^{50}$ See L Boon Kuo, Policing Undocumented Migrants: Law, Violence and Responsibility (Taylor \& Francis, London 2017).

${ }^{51}$ Bishop made this comment in relation to Land of the Dead (2005), in which Dennis Hopman's character Kaufman constructs the world's most 'extreme border security', with fences, blown up bridges, guards and an apparently impassable river. To state the obvious, this border security is breached in Land of the Dead: K Bishop, 'Dead Man Still Walking' (2009) 37(1) Journal of Popular Film and Television 16, 24.

52 See D Bigo, 'Security and Immigration: Toward a Critique of the Governmentality of Unease' (2002) 27 (Issue 1 Supplement) Alternatives 63, 65 .

53 After all, if monsters were defeated at the beginning there would be no horror story. They are only defeated (if at all), at the end with extreme measures - which then in and of itself has the potential to undermine the humanity of the hero/ine. 'He who fights with monsters should look to it that he himself does not become a monster. And if you gaze long into an abyss, the abyss also gazes into you.': F Nietzsche, Beyond Good and Evil [1886] (Allen \& Unwin, UK 1967) 46, trans H Zimmern. 
monsters will not succeed. The zombies in World War $Z$ cannot just be killed - their heads must be destroyed. The rotting dead cannot be restored to reason or reasoned with. Walls, like that around Jerusalem, will not keep the zombie plague out. In World War Z, Gerry proposes an extreme but unsustainable solution towards the end of the film of infecting the living with a mortal disease because the zombies avoid anyone who is already sick or dying. The effect of constructing refugees as monstrous is similar. Extreme measures are justified and required in response to the 'threat' of refugees. Under international refugee law, asylum seekers cannot simply be expelled using 'ordinary' state tactics of deportation, since they have a unique right of entry without invitation or the permission of the host state. Dauvergne has highlighted that, as a result, refugees are the only subjects who interrupt the notion that the sovereign state has complete control over its borders and may finally determine who enters and on what terms. ${ }^{54}$ Beyond this if they are found to be refugees, asylum seekers possess the right of nonrefoulement. ${ }^{55}$ That is, they have a right of non-return, such that even if they are assessed as security threats to the host state they may not be returned to their country of origin. In this sense, as with monsters, the standard response to the threat of the non-citizen - that is, expulsion - is ineffective and unavailable. While refugees can be interned, they cannot be entirely contained. The threat they represent is that they cannot be stopped (at the border), fully contained or expelled once inside the territorial state.

The zombie, who has been described as a 'transnational' figure, unsettles geopolitical and cultural attempts at insulation, as well as the 'cultural and political walls' separating the West from postcolonial and less-developed states.$^{56}$ The zombie genre tends to portray an apocalyptic world involving the breakdown of the geo-political state and a resulting interrogation of legal rights that are increasingly seen as luxuries or non-existent. ${ }^{57}$ In World War Z, the zombie reveals the 'porous geopolitical structure of global society' so completely that we are left without any sense of place, state or nation. ${ }^{58}$ In response to the failure of the nation-state, images and references to the global and the transnational recur throughout the film as sites and symbols of safety, as well as a kind of strategic response. The hero of the film, Gerry, supposedly represents the United Nations in a global zombie war. Indeed, the UN is the body leading the fight against the zombie pandemic. ${ }^{59}$ Just like the film's 'good guys', the safe places are cast as 'international'

54 C Dauvergne, Making People Illegal: What Globalization Means for Migration and Law (Cambridge University Press, Cambridge 2008).

${ }^{55}$ Convention Relating to the Status of Refugees (adopted 28 July 1951, entered into force 22 April 1954) 189 UNTS 137 (Refugee Convention); Protocol Relating to the Status of Refugees (adopted 31 January 1967, entered into force 4 October 1967) 606 UNTS 267 (Protocol).

${ }^{56}$ K Slotwinska, 'The Rising Multitudes: Zombie Invasion and the Problem of Biopolitics in Max Brooks' World War Z' (2015) 9 Polish Journal for American Studies 151, 152.

${ }^{57}$ B Arnold, 'Is the Zombie My Neighbour: The Zombie Apocalypse as a Lens for Understanding Legal Personhood' (2016) 14(1) Canberra Law Review 25.

${ }^{58}$ Slotwinska (n 58).

${ }^{59}$ The 'international' UN portrayed in World War Z is however primarily American. The language spoken is primarily English. Gerry is transported and protected primarily by the American army. 
zones and the absolute safest place in the film is on a naval boat on the Atlantic sea - a clear inversion of the boat and the ocean as a site of danger and death for migrants on the move.

As well, in a elear critique of the hermetic, sealed off nation state as the paragon of safety, the viewer experiences a sense of constant movement and flight across vast spaces and territory. This constant movement comes across as an ethos, and impediments to movement usually result in death. At one point, Gerry patronizingly explains to a Mexican family too scared to leave their home and seeking to barricade themselves in: 'I worked in dangerous places. Those who moved survived, those who stayed didn't'. This is followed by the almost parable-like phrase 'movement is life' (to the same Mexican family, as if they didn't know). As well as movement across territory as life, national references, such as the 'Belarus Air' plane that Gerry uses to escape a zombie encounter, are presented as almost quaint and things of the past, since the present is 'just survival.' Each time Gerry arrives in a new place, the audience is carefully advised of its location via militaristic subtitles - but each time he departs an area, zombies are in the process of taking it over and geopolitical distinctions have collapsed.

Finally, the cinematography of the film is saturated with aerial shots that flatten and denationalize territory. Most shots focus on carpets of zombies spread across territory and, in the case of the New Palestine, on both sides of the now-redundant border wall. As with so many images of refugees and migrants in transit, the zombie images are rarely 'located' and the zombies are presented as a denationalized and hostile mass. The threat is generalized and borderless - and World War Z is marked by the collapse of borders in a post-apocalyptic world.

World War Z's film production itself traversed international boundaries, with filming in Malta, Scotland, England and Hungary and aboard a Royal Fleet Auxiliary ship. Production was consistent with the theme of breach of international borders, with Glasgow, Scotland made to appear as a financial district in Philadelphia, and with an original aim to present Budapest as Moscow. In addition, film makers were charged with breaching customs laws in Budapest, Hungary. The film-set was raided by the Hungarian Counter Terrorism Centre because the 85 assault rifles, sniper rifles and handguns that had been flown into Budapest had not been cleared by the Hungary's Anti-Terrorist Unit. The importation documentation indicated that the weapons had been disabled, but they were fully functional. Criminal charges were dropped in February 2012, as investigators were unable to establish who had ownership rights and therefore who was responsible. ${ }^{60}$

60 'Counter-terrorism police seize World War Z machine guns', news.com.au, 11 October 2011,

http://www.news.com.au/entertainment/movies/counter-terrorism-police-seize-machine-guns-from-world-war-zset/news-story/a416e1559e38b9ef00348ba893945ebd (accessed 28 November 2017); Z Johnson, 'SWAT Team Raids Brad Pitt's World War Z Set', Us Magazine, 10 October 2011,

https://www.usmagazine.com/entertainment/news/swat-team-raids-brad-pitts-world-war-z-set-20111010/ (accessed 28 November 2017) 


\section{iii. Origins of the Monster/Refugee: Where does the monster come from?}

A key plot device and theme in the horror genre is the question of the origin of the monster. ${ }^{61}$ This reflects a question of philosophy and theology - from whence does evil come? ${ }^{62}$ The historical zombie is a figure associated with imperialism and slavery, and in particular with black bodies 'raised from the dead to labor [sic] in the fields' ${ }^{63}$ The term itself is rooted in slavery, stemming from Haitian lore and introduced into Anglophone texts to describe a soulless figure, raised by voodoo from the dead to work as alienated, enslaved labour. ${ }^{64}$

In the early $20^{\text {th }}$ century, zombies were racially marked as Haitian creatures, ${ }^{65}$ and as undead and soulless bodies emblematizing how slavery reduced person to things. ${ }^{66}$ As Morrell observes, mechanical men and the living dead have 'long been working together in US literature of the nineteenth and early-twentieth centuries to embody the dehumanizing effects of racial oppression and relatedly labour exploitation' ${ }^{67}$ By contrast, late $20^{\text {th }}$ and certainly $21^{\text {st }}$ century American films have morphed the zombie 'into a convenient bogeyman representing various social concerns' ${ }^{68}$ Many more recent zombie films like World War $Z$ have combined zombie narratives with fears of contagion, contamination and plague such that the threat - like the threat of floods of refugees - becomes generalized, denationalized and dehistoricized. This 'zombie apocalypse' trope is characterized by entire communities, whole countries and 'even the world' being

\footnotetext{
${ }^{61}$ Sometimes the backstory or explanation of a monster is not given at all. This lack of explanation can also be terrifying. For example, in It Follows (2014), no explanation is given for the monster at all. It just is.

62 A religious perspective labels this as a problem of evil. If evil and suffering exist, then God is either not omnipotent, not omniscient, or not perfectly good. A classic explanation for this is that evil is not a positive presence, but an absence of grace or distance from God. See for example, T Aquinas, On Evil [1274] (Oxford University Press, New York 2003). This kind of classic, negative model of wickedness is rarely if ever portrayed in horror - as it lacks the magisterial, entertaining character of a positive, mythical, monstrous wickedness. See further, M Midgley, Wickedness: A Philosophical Essay [1984] (Routledge, New York 2001) 222.

${ }^{63}$ S J Lauro and K Embry, 'A Zombie Manifesto: The Nonhuman Condition in the Era of Advanced Capitalism' (2008) 2 Boundary 85, 87. And see H W Ackermann and J Gauthier, 'The Ways and Nature of the Zombie' (1991) 104 The Journal of American Folklore 466.

64 S Morrell, 'Zombies, Robots, Race, and Modern Labour' (2015) 2(2) Affirmations: of the Modern (online) 101. Certain early $20^{\text {th }}$ century American depictions located the origin of the zombie in sinister or 'evil Haitian religions (White Zombie (1932); I Walked with a Zombie (1943)): see Slotwinska (n 58). The anthropologist Joan Dayan argues that "the zombie tells the story of colonization: the reduction of human into thing for the ends of capital. For the Haitian no fate is to be more feared.' For Dayan, the zombie provides an explanation of the destruction of Haitian culture by American colonialism disguised as development: J Dayan, 'Vodoun, or the Voice of the Gods', in M Fernandez Olmos and L Paravisini-Gebert (eds.), Sacred Possessions: Vodou, Santeria, Obeah, and the Caribbean (Rutgers University Press, New Brunswick 1997) 33. Though note that Morrell argues that the figures resembling the mindless, mechanical living dead appeared in American texts well before the zombie was introduced. ${ }^{65}$ C Kee, 'Good Girls Don't Date Dead Boys: Toying with Miscegenation in Zombie Films' (2013) 42(4) Journal of Popular Film and Television176. See also W Seabrooke, The Magic Island [1929] (Lancer, New York 1968). ${ }^{66}$ S Morrell, 'Zombies, Robots, Race, and Modern Labour' (2015) 2(2) Affirmations: of the Modern (online) 101. ${ }^{67}$ Ibid.

${ }^{68}$ S J Lauro and K Embry, 'A Zombie Manifesto: The Nonhuman Condition in the Era of Advanced Capitalism' (2008) 2 Boundary 85, 87. For example, Kee argues that zombie rom-com films such as White Zombie (1932), My Boyfriend's Back (1993) and Warm Bodies (2013) 'toy with fantasies of miscegenation': C Kee, 'Good Girls Don't Date Dead Boys: Toying with Miscegenation in Zombie Films' (2013) 42(4) Journal of Popular Film and Television 176,177
} 
'subject to destruction by increasing numbers of zombies that appear from nowhere, often originating as a consequence of radiation from outer space - that is, if any rationale for their existence is proffered' ${ }^{69}$ Or as Pokornowski argues, the post 9/11 zombie was remoulded by Western society as a biomedical, denationalized, 'foreign' monster that threatened 'the racial and sexual purity of the West—especially the US' ${ }^{70}$

The racialised threat of the refugee-zombie is also the precise subject of an art series created by Australian academic and artist Safdar Ahmed. Ahmed argues that as a figment of paranoia and revulsion, 'the zombie is about more than our current fear of terrorism. It is a looking glass for all the weird dreams and vivid hallucinations of modern Islamophobia' and with them, conceptions of 'Muslim barbarism and lack of moral feeling. ${ }^{71}$ Ahmed's fabulous propaganda-style posters include images of blood hungry refugees on overcrowded boats captioned, 'Zombie Boat People: They Jump Queues to Jump You'; in another image, 'Muslim Zombies' dressed as clerics and eating dismembered hands warn viewers of 'Creeping Sharia', framed by the words 'more theft... more hands'. ${ }^{72}$

Significantly, in World War Z, with the destruction and increasing irrelevance of the nation states comes a flattening of past global relations, of the uneven distribution of resources, and of histories of colonialism and racial and social inequalities. In the zombie war, everyone or every human is apparently equally and equal in danger. While the book functions as an explicit critique of US hegemony and exploitation of postcolonial states and resources, ${ }^{73}$ the issue of economics, race and responsibility for the zombie war is at best sidestepped or erased altogether in the film. One reason for this is certainly the political economy and general crappiness of blockbuster films. For example, it was reported, but later denied, that Paramount had cut the scene where characters speculate that the zombie outbreak originated in mainland China in hopes of landing a

${ }^{69}$ J Stratton, 'Zombie trouble: Zombie texts, bare life and displaced people' (2011) 14(3) European Journal of Cultural Studies 26, 26.

${ }^{70}$ S Pokornowski, 'Vulnerable Life: Zombies, Global Biopolitics, and the Reproduction of Structural Violence' (2016) 5(3) Humanities 71, 13/22.

${ }^{71}$ Ahmed (n 20).

${ }^{72}$ S. Ahmed, Zombie Boat People (water colour on gauche, 2012) and Stop Creeping Sharia! (digital image, 2012) https://safdarahmed.com/artworks/muslim-zombies/ (accessed 14 November 2017).

${ }^{73}$ Not all critics are persuaded by the political critique of World War Z: An oral history of the zombie war. Lanzendorfer regards the novel as a demonstration of the limits of a progressive liberal imagination, with many of the underlying structures that caused the apocalypse remaining in place at the novel's conclusion: T Lanzendorfer, 'Max Brooks's World War Z: An Oral History of the Zombie War: Conservative Armageddon and Liberal PostApocalypse' (2014) 41 Literature in North Queensland 112. 
distribution deal with that county. ${ }^{74} \mathrm{~A}$ long battle scene against the zombies on Russian territory was also removed to ensure the film remained a friendly summer release. ${ }^{75}$

All the same, in the novel, although the exact origin of the plague is unknown, a young boy from a village in (exotic, fetid) China is identified as patient zero. In the film, the zombies themselves are not raced and if anything they are white or white-ish. The zombies' origin is difficult to determine since, once zombified, their skin is green, decayed and decrepit. Most of the zombies that the film zooms in on are not noticeably raced beyond their zombie status, and the same can be said for the zombie hordes. The Hollywood film's colonizing of the zombie figure and the threat it presents not only erases race but takes a figure that represented the threats of colonization, slavery and racial oppression to express white, colonial anxieties about racialized invasion. ${ }^{76}$

There are remarkably clear parallels between the contemporary zombie film presenting the zombie threat as one that is generalized, detached from economics, race, politics, culture and history; and the representation of the 'migrant crisis' as a general threat to a beleaguered, innocent Europe. Europe and other 'refugee destination' states are at best called upon to act humanely or in a humanitarian manner towards refugee arrivals. They are certainly not required to contextualize and take responsibility for their own part in the arrival of refugees and migrants at their borders or on their shores.

Danewid and others have compellingly critiqued the discourse of 'hospitality' and the fetishization of the stranger, as well as the shift from politics to ethics, when discussing the European response to migrants, via the concept of the 'Black Mediterranean'. As Danewid writes:

The term 'Black Mediterranean' has recently started to surface amongst academics, artists, and activists to describe the history of racial subordination in the Mediterranean region. Inspired by Paul Gilroy's Black Atlantic, the 'Black Mediterranean' invites us to place the contemporary migrant crisis in the context of Europe's constitutive history of empire, colonial conquest, and

\footnotetext{
${ }^{74}$ L Shaw, 'Fearing Chinese Censors, Paramount Changes 'World War Z' (Exclusive)', The Wrap, 31 March 2013 https://www.thewrap.com/fearing-chinese-censors-paramount-changes-world-war-z-exclusive-83316/ (accessed 28 November 2017); L Shaw and S Waxman, 'Insider: China Censors Rejected Brad Pitt's 'World War Z'

(Exclusive)', 3 June 2013, https://www.thewrap.com/brad-pitt-world-war-z-china-rejecting-zombie-apocalypse95051/ (accessed 28 November 2017).

${ }^{75}$ The film also opened the $35^{\text {th }}$ Moscow International Film Festival. MacNeil also points out Brad Pitt's production company bought the rights to the book, and Pitt was one of the film's producers: MacNeil (n 2).

${ }^{76}$ While, as Morrell observes the idea of the zombie as a soulless slave may have receded in Hollywood and the global north, it has gained strength in in the so-called developing world experiencing new forms of millennial capitalism and alienated labor: S Morrell, 'Zombies, Robots, Race, and Modern Labour' (2015) 2(2) Affirmations: of the Modern (online) 101. See also J Comaroff and J Comaroff 'Alien-Nation: Zombies, Immigrants, and Millennial Capitalism' (2002) 101(4) The South Atlantic Quarterly 779.
} 
transatlantic slavery. As [Saucier and Woods] explain, the Mediterranean 'has been an ongoing crisis for black people for the better part of the past and present millenniums [sic]'. ${ }^{77}$

Danewid argues that the Mediterranean crisis should not be viewed 'as a moment of exception or as a discrete event in time but, rather, as a late consequence of Europe's violent encounter with the Global South' ${ }^{78}$ This reading highlights the fact that history of European modernism has long been based on designating who is human/inhuman and whose life (and death) is human life and counted as such. In mounting this critique, Danewid also interrogates and rejects the 'new humanism', in particular Butler's Grievable Life, as the basis for political engagement. As she puts it, focussing on abstract as opposed to historical humanity - and in particular on bodily vulnerability, loss and mourning - contributes:

to an ideological formation that disconnects connected histories and turns questions of responsibility, guilt, restitution, repentance, and structural reform into matters of empathy, generosity, and hospitality. The result is a colonial and patronising fantasy of the white man's burden - based on the desire to protect and offer political resistance for endangered others - which ultimately does little to challenge established interpretations that see Europe as the bastion of democracy, liberty, and universal rights. ${ }^{79}$

Danewid's impressive critique of both Butler's and Levinasian's responses to the migrant other maps onto the evacuation of race from the film version of World War Z. While in the film the head of the UN, Thierry Umutoni, is a person of colour, there is essentially no reference to race relations except in the fall of Jerusalem scenes, in which Israel has miraculously allowed the entry of all Palestinians, and conceded the territory as the New Palestine, where everyone is living in harmony (which, as noted, is their downfall) ${ }^{80}$ In Australia, too, refugee arrivals and asylum seeking seekers are spoken about in general, dehistoricized terms. There is seldom Rreference is seldom made to the history of Australian colonialism in the states now hosting Australia's ignominious offshore refugee processing centres, Nauru and Manus Istand (in-Papua New Guinea). Behrooz Boochani, an Iranian journalist ${ }_{2}$ and writer and refugee who has been held-imprisoned on Manus Island for over four years, has persistently critiqued this dehistorcized approach, writing that:

Only a meta-historical and transhistorical approach can unpack the peculiarities associated with the issue of Manus [in Papua New Guinea] and Nauru. Only a rigorous analysis of a colonial presence in Australia and its tactics in the region can disclose the reality of violence in these

\footnotetext{
${ }^{77}$ I Danewid 'White innocence in the Black Mediterranean: hospitality and the erasure of history' (2017) 38(7) Third World Quarterly, 1674, 1679.

${ }^{78}$ Ibid.

${ }^{79}$ Ibid, 1675

80 The collapse of Jerusalem in the film implies that if only the walls had remained firmly shut Jerusalem would have survived. Herzberg states that this was not the filmmakers' intentions, suggesting instead that they probably wanted to give a boost to the battered ideals of internationalism: Hertzberg (n 15).
} 
island prisons.... This form of affliction, inflicted on people in similarly vulnerable situations, has always existed in the history of modern Australia. Pain and suffering systematically inflicted on defenceless and vulnerable bodies. ${ }^{81}$

While the film critiques the securitization of migration more generally, the refusal to historicize the zombie crisis or the contagion that comes with it, means that the film falls well short of the novel, which directly links the spread of the virus as a result of US ilmperialism, due to the trafficking of organs and migrants into the Global North. The film also falls short of critical approaches to the unresolvable deadness and aliveness of the zombies, with its primary orientation being towards Gerry Lane, his family, and anyone who is not infected, as opposed to interrogating the line between human/inhuman. The film shows a willingness to sacrifice characters, such as the academic who is the key to saving the world, however this is usually done too quickly for us to care for them at all and used mainly as a plot device to highlight the impossibility of Gerry's quest.

Throughout the film we of course know that white, American, saviour Brad Pitt (Gerry Lane) will survive and is never really at risk. As with the purported lottery of citizenship, the film repeats the hollowness of the 'there but for the grace of god' approach as a basis for empathy because we know that Brad Pitt is not at risk, but he is called upon to 'save' those who are. The zombie apocalypse may be indiscriminate and disregard national borders, but inevitably its effects will be felt more acutely in some parts of the world than others, depending on the level of development and the ability to adapt. ${ }^{82}$

\section{World War Z's 'Other' Refugees: Gerry and his Family}

While we have focused on echoes of contemporary refugees and refugee 'crises' in the zombie hordes in World War Z, we argue that the film presents an additional, alternative refugee narrative. The first refugee group, the zombies, are those we do not care about and from whom we need protection since they are soulless, mindless and lack the capacity for thought or emotion. ${ }^{83}$ However, there is a second, powerful refugee narrative in World War $Z$ and the zombie genre generally - that of the uninfected. These are the survivors, people such as Gerry and his family, who are trying to escape the zombie menace. This reflects and reinforces the fear

${ }^{81}$ B Boochani, 'I write from Manus Island as a duty to history', The Guardian, 6 December 2017, https://www.theguardian.com/commentisfree/2017/dec/06/i-write-from-manus-island-as-a-duty-to-history (accessed 22 May 2018).

${ }^{82}$ Heilikmann makes this point in relation to the effects of both climate change and the zombie apocalypse: I Heilikmann (n 49) 66.

${ }^{83}$ There is irony here, since the historical raced and enslaved zombie as it was presented in American $19^{\text {th }}$ century texts functioned precisely to express 'the denial or loss of self experienced by slaves, workers and victims of racial oppression': S Morrell, 'Zombies, Robots, Race, and Modern Labour' (2015) 2(2) Affirmations: of the Modern (online) 101. 
of zombies analyzed above: in disrupting and transgressing borders, the zombies themselves are refugee-producing and destabilize the boundaries between the safe and the infected.

World War Z begins and ends with Gerry's family. Despite the collapse of states, geo-political boundaries, economic systems and much social infrastructure, the 'family' retains its talismanic power. ${ }^{84}$ The film starts in Gerry's home in the marital bed with his wife Karen, with their two daughters soon jumping into bed with them. The film can be read as a quest for Gerry to keep his family safe by migrating away from danger to places of perceived safety. We do not recognize these bodies in flight as refugees since they are from the Global North rather than seeking entry to it - even though a state of emergency or exception is now the global norm. Yet the Lane family are clearly seeking refuge. On the safe UN Command Ship on the Atlantic Ocean, the familyy are-is only granted sanctuary on the condition that Gerry leaves them to save the world. The family is warned 'there is no room for non-essential personnel'. The threat is shown to be real when other families on the ship are sent away for 'immediate relocation'. The film provides depersonalized shots of the families being relocated, so we are not particularly encouraged to identify with or care for even these families. Only Gerry and his family generate emotional investment by the audience.

As the plot unfolds, the Lane family begin to live like refugees: 'life is denied its political quality as the 'bare essentials' for species survival take precedence'. ${ }^{85}$ They are not made welcome on the UN Command Ship. When lining up for food in the mess-hall they are pointedly told by a soldier that 'there are too many people on this ship'. They are given sanctuary but this is at best precarious. Within 14 hours of Gerry being believed dead, his family are unceremoniously dispatched to the 'Freeport Safe Zone Refugee Camp' in Nova Scotia. However, in contrast with the hordes of undifferentiated refugees/zombies, these are characters who are forced into migration and whose survival we actually are positioned to care about. This is a story of refugees that differs from the official state story. The Freeport Zone Refugee Camp is explicitly depicted as a place of danger. When he hears of his family's transfer to the Safe Zone, Gerry states unequivocally that 'they're not safe'. By implication, no one else in the camp is safe, but the Lane family both deserve and will be afforded safer conditions.

In contrast with other refugee stories (and the absence of any 'individualized' stories available to the public), Gerry's motives are completely understandable. His primary focus throughout the film is upon his family. When he thinks he is going to die he holds up a sign to the laboratory camera that reads, 'Tell my family I love them'. In addition, Gerry is not disempowered as a refugee. His phone is provided by the UN and seems capable of working and maintaining contact

${ }^{84}$ Admittedly the film does portray an expanded concept of the family by allowing the son of the immigrants to remain with the Lane family. If the UN was truly doing what was necessary, he should have been sent from the ship straightaway.

${ }^{85}$ B Evans, 'Foucault's Legacy: Security War and Violence in the 21st Century' (2010) 41(4) Security Dialogue 413, 420 . 
despite the collapse of infrastructure in most of the places that he visits. People die to save him including after an unfortunately timed phone call by his wife 'wakes' the zombies. He also has the power to demand resources. He is escorted out of Israel even as it is collapsing. He successfully demands a change of flight plan path on a commercial flight, and achieves entry into the quarantined Centre for Communicable Diseases.

Gerry and his family are exceptional refugees. We sympathize with their motives and their need to seek protection. This is at odds with common representations of 'bogus' refugees or 'queue jumping' migrants, who are presented as opportunistic, selfish and unprincipled in their quest for 'better' lives. Consistent with the portrayal of monsters, refugee motives are either incomprehensible (they cannot be understood by us) ${ }^{86}$ or are presented as driven by an unacceptable desire for material wealth, capitalism's riches or pure, untrammeled consumption.

A central theme of zombie films is consumption. After all, zombies are the ultimate consumers their only drive is to consume. Whilst the novel gestured toward global consumption - including illegal organ transplants - as an explanation for the zombie apocalypse, ${ }^{87}$ these suggestions were removed from the film. However, the film does retain a classic narrative of consumption in the quest for security and sustenance by the Lane family. Like zombies, the refugees generated by a zombie apocalypse need to consume to survive. In the zombie genre the living frequently take refuge in and/or visit shopping malls for safety and sustenance. ${ }^{88}$ In an early scene in World War $Z$, the family visit a supermarket to get essential supplies including medication. Everyone, regardless of their class, race, age, and/or disability, requires sustenance to survive. Although the zombie infection has only just begun, the supermarket is a center of chaos and danger - Gerry's wife is almost raped in front of one of their daughters, and Gerry uses a gun to steal a car from the parking lot. The zombie genre portrays a post-apocalyptic society in which there are insufficient and dwindling resources available. Consumption is integral to survival - of both the zombies and the living. ${ }^{89}$

The foregrounding and problematization of consumption in the zombie genre parallels rhetoric of political and legal constructions of refugees and migrants. In the contradictory and overlapping discourses on the undesirability of refugee entrants, asylum seekers are cast as impatient, unwanted 'queue jumpers'. Asylum seekers at the border are counterpoints to humanitarian

${ }^{86}$ P Cole, The Myth of Evil (Edinburgh University Press, Edinburgh 2006); P Crofts, 'Monstrous Wickedness and the Judgment of Knight' (2012) 21(1) Griffith Law Review 72.

${ }^{87}$ Lanzendorfer criticizes the novel for failing to fully criticize the totalizing, global economic structure: $T$ Lanzendorfer, 'Max Brooks's World War Z: An Oral History of the Zombie War: Conservative Armageddon and Liberal Post-Apocalypse' (2014) 41 Literature in North Queensland 112.

${ }^{88}$ In Dawn of the Dead $(1978,2004)$, the four survivors play in the shopping mall in scenes of 'consumerism gone mad': D Skal, The Monster Show (Faber, New York 1993) 309. See also Land of the Dead (2005), in which the wealthy elite live in a gated community protected from the zombies and the lower class.

8928 Weeks Later (2007) begins with the premise that the majority of zombies depicted in 28 Days Later (2002) have starved, thus permitting resettlement. 
entrants, who wait passively and patiently encamped in 'developing' countries until invited into host states. However, worse yet are 'pure economic migrants' who are the counterpoint to 'good' and genuine refugee entrants and whose primary offence is seeking access to the (apparent) wealth and comforts of life in the West. The casting of asylum seekers as mere and unwelcome economic migrants has dominated political rhetoric in Australia. Infamously, in 2017 Australian Immigration Minister Peter Dutton not only claimed that refugees held in Australia's offshore camps were all undeserving economic migrants, but that they were 'Armani refugees' with 'the world's biggest collection of Armani jeans and handbags' ${ }^{90}$ Relevantly, an 'economic' and material motive for migration is self-evidently illegitimate and reprehensible, with no further explanation required.

The flight of Gerry and his white family is presented as both rational and relatable. By contrast, we are not positioned to spare even a thought for the 'plight' of the zombies. Even at the end of the film, when a temporary solution in the form of an anti-zombie vaccine has been discovered, the response to the zombie masses, whom we see being rounded up and firebombed, is no less extreme. As one film critic put it, the World War Z zombies are 'allowed no moments of pathos' and, unlike in other zombie texts, Pitt is 'excused the anguish of confronting his affinity with the estranged' ${ }^{91}$ The experience of the damned isn't dwelled on, as it doesn't matter. ${ }^{92}$ Ironically, the Lane family would not necessarily meet the Refugee Convention definition of who qualifies for protection. Under international law, the Lane family would not be characterized as refugees, as 'no matter how devastating may be the epidemic, natural disaster or famine, a person fleeing them is not a refugee with the terms of the Convention' ${ }^{93}$ Whilst the film encourages us to sympathize with the Lanes' plight, ${ }^{94}$ the Refugee Convention protection does not, in the absence of individualized persecution, extend to people in pursuit of better living conditions or victims of natural disasters., even if 'both of these cases might seem deserving of international sanctuary'. This is the case 'even when the home state is unable to provide assistance' ${ }^{95}$ Although this has led some to argue we need an expanded definition of a refugee, which ${ }^{96}$-extendsing beyond the

${ }^{90}$ M Koziol, 'Armani refugees': Peter Dutton accused of undermining US deal with 'extraordinarily irresponsible' critique', Sydney Morning Herald, 29 September 2017, https://www.smh.com.au/politics/federal/armani-refugeespeter-dutton-accused-of-undermining-us-deal-with-extraordinarily-irresponsible-critique-20170928-gyqidd.html (accessed 22 May 2018)

${ }^{91}$ D Cox, 'World War Z unleashes an unedifying breed of zombie', The Guardian, 17 June 2013, https://www.theguardian.com/film/filmblog/2013/jun/17/world-war-Z-zombies-brad-pitt (accessed 22 May 2018). 92 Ibid.

${ }^{93}$ Applicant A v Minister for Immigration and Ethnic Affairs [1997] HCA 4; (1997) 190 CLR 225, 248 (Dawson J).

${ }^{94}$ The film does not really encourage empathy for many other characters. When other passengers are

unceremoniously ejected from the ship, the film's primary concern is whether or not the Lane family will also be ejected.

${ }_{95}$ Canada (Attorney General) v Ward [1993] 2 SCR 689, 732; J McAdam, Climate Change, Forced Migration, and International Law (Oxford University Press, Oxford 2013).

${ }^{96}$ K Musalo et al, Refugee Lew and Policy: A comparative and international approach 36 (Carolina Academie Press, North Carolina 2007) 36. 
liberal and individualized categories prioritized by the 1951 Convention drafters, ${ }^{97}$ World War $Z$ positions us to see that with the 'end' of the nation state comes the end of both international refugee law and indeed of a clear line between the worthy uninfected human and infected zombie. Since there is no remaining order of sovereign states to provide the basis for either refugee status or any responsibility to protect, the question of the 'genuine' individual refugee in contrast with the undifferentiated masses seeking safety falls away.

\section{Conclusion}

Agamben's idea of 'bare life' has been insightfully applied to refugees, and academics have extended this idea to the commonalities of the bare life of refugees and zombies. This article has taken the labelling of refugees as zombies-dehumanized seriously, and has considered the ways in which the label is applied and the implications of characterizing refugees as zombies. It has analyzed refugees and governmental responses to the never-ending 'crisis' through the prism of World War $Z$ and monster theory. ${ }^{98}$ World War $Z$ and other zombie texts provide a means to both represent contemporary anxieties about dehumanized refugees and asylum seekers, and to critique 'dead end' Government responses to such fears, including fortifying the territorial state as a means of combatting or controlling the zombie invasion.

Key to the characterization of refugees as zombies is the transgression of borders. The horror genre is a meditation on the horror of that which breaches boundaries. Zombies, as de-identified and displaced masses, who collectively disregard and cross borders to find 'new life', are a privileged monster in contemporary society. World War Z depicts the worst fears of border breaches with the spectacular collapse and consequent irrelevance of the geopolitical, territorial state. The label of monster (or monstrous wickedness) is instrumental, as it justifies and requires extreme measures. World War $Z$ does not depictconvey any sadness in at the resolution extermination of the zombies. Slaying them, through destruction of their heads, is the only response.

The horror genre attracts its consumers by trafficking in the sorts of things that cause disquiet, displeasure and repulsion. ${ }^{99}$ Monsters enact and perform that which we would normally repress the abject, disorderly, undecided and/or uncanny ${ }^{100}$ - and in the process demonstrate the radical and sickening permeability of borders. ${ }^{101}$ Much state refugee policy is geared toward the

${ }^{97}$ K Musalo et al, Refugee Law and Policy: A comparative and international approach 36 (Carolina Academic Press, North Carolina 2007) 36; Heilikmann (n 49).

${ }^{98}$ Sassen argues that rather than characterizing refugees as a crisis, we should deal with refugees as we would with education or health. The characterization of refugees as a 'crisis' (and we would argue as zombies) justifies extreme and urgent policy. See S Sassen, 'Migration Policy: From Control to Governance, openDemocracy, 12 July 2006,

http://www.opendemocracy.net/people-migrationeurope/militarising_borders_3735.jsp (accessed 22 May 2018).; S Sassen, Losing Control? Sovereignty in an Age of Globalization (Columbia University, New York 1996).

${ }^{99} \mathrm{~N}$ Carroll, The Philosophy of Horror: Or, Paradoxes of the Heart (Taylor \& Francis, London 1990) 158.

100 S Freud, The Uncanny (Penguin Books, New York 2003) 132.

101 C Valier, 'Punishment, Border Crossings and the Powers of Horror' (2002) 6(3) Theoretical Criminology 319. 
silencing, repression or denial of the horrors of migration. The horror genre provides 'a safely distanced and stylised means of making sense of and coming to terms with phenomena and potentialities of experience which under normal (i.e. functional) conditions would be found too threatening and disturbing'. ${ }^{102}$ Despite its intentional depoliticization in order to sell as a blockbuster film, World War $Z$ depicts some of that which is intended to remain secret and hidden away. In its erasure of colonial histories and global inequalities in narrating the 'origin' of the zombie war and the refugee crisis, World War $\mathrm{Z}$ mirrors the erasure of race and race relations in the casting of refugees as invading and disorderly hordes. The film, in accordance with much of the zombie genre, gives an alternative narrative of refugees whom we actually care about that of Gerry and his family - and shows disparities of treatment not only amongst the infected and uninfected, but also the useful and the 'non-essential' uninfected, and in the process, reveals the limitations of existing national and international protocols.

In examining the refugee crisis (or the 'war on refugees', as it is often called)-through the war on zombies in World War Z, we agree with MacNeil's argument (in reading The Walking Dead, The Rising and World War Z) that the stakes are high in zombie fiction because it forces us to rethink our law and society; or nomos (law and norms) and notos (home/ household/ family). ${ }^{103}$ The choice is not, as MacNeil points out, to give ourselves over to the zombie apocalypse or to return to the 'good' old world order. Rather we need to accept the 'both/and' or the 'dead and undead' formulation of the zombie as undermining the failed categories of citizen/non-citizen or 'authorised/unauthorised' and of course, 'zombie/human.'

102 J Grixti, Terrors of Uncertainty: The Cultural Contexts of Horror Fiction (Routledge, London and New York 1989) 164.

${ }^{103}$ MacNeil (n 2) 116 